\title{
Levelling Shakespeare: Local Customs and Local Texts
}

\author{
Leah S. Marcus
}

\begin{abstract}
$\mathrm{M}$ AJOR CHANGES ARE AFOOT. DURING THE LAST TEN YEARS, there has been among Shakespeareans a growing discomfort with the time-honored editorial practice by which variant early texts are ranked hierarchically on the basis of their fidelity to a presumed Shakespeare "original." According to that practice, at least as it is reflected in standard twentieth-century editions, the texts that rank "high" are accorded lavish editorial attention while the texts that rank "low" are assigned to a curious limbo in which they can be mined for individual readings but are assumed to be debased derivatives of Shakespeare with no claim to unity or artistic integrity.

Since the pioneering work of Steven Urkowitz, Gary Taylor, and Michael Warren, Quarto texts previously regarded as low and contaminated versions of the plays are coming to be regarded as different instead of debased, as encoding distinct patterns of meaning worthy of consideration in their own right rather than as mere disfigurement of the "true" version. ${ }^{1}$ This development is by no means unfamiliar to most readers of Shakespeare Quarterly; what perhaps deserve more emphasis are the ways in which our new attention to "low" texts of the plays can be coordinated with a new critical interest in "low," popular materials within the plays and with local interpretation more generally.

How can we use the new Shakespearean textual studies to open up the plays to "local" interpretation of a kind that has been unavailable before? And, just as important, how can our interest in local customs and topography help us to analyze different early versions of a single play? My use of the term "levelling" is adopted from early modern folk custom, where it can refer to the temporary, carnivalesque overthrow of social hierarchy or to longer-term social reform based roughly on the carnivalesque model, as in the Leveller Party of the Civil War period in England. I use the term here to characterize a similar recent disruption of hierarchical thinking in our
\end{abstract}

\footnotetext{
${ }^{1}$ Steven Urkowitz, Shakespeare's Revision of King Lear (Princeton, N.J.: Princeton Univ. Press, 1980); Gary Taylor and Michael Warren, eds., The Division of the Kingdoms: Shakespeare's Two Versions of King Lear (Oxford: Clarendon Press, 1983). For more recent work in a similar vein, see Urkowitz, "Reconsidering the Relationship of Quarto and Folio Texts of Richard III," English Literary Renaissance, 16 (1986), 442-66; and "Good News about 'Bad' Quartos" in "Bad" Shakespeare: Revaluations of the Shakespeare Canon, Maurice Charney, ed. (London: Associated Univ. Presses, 1988), pp. 189-206; Annabel Patterson, "Back by Popular Demand: The Two Versions of Henry V," Renaissance Drama, 19 (1988), 29-62; and Michael Warren, "Doctor Faustus: The Old Man and the Text," ELR, 11 (1981), $111-47$. My arguments for localism here in part derive from my Puzzling Shakespeare: Local Reading and Its Discontents (Berkeley: Univ. of California Press, 1988) and anticipate my book in progress under the working title of "Unediting the Renaissance: Shakespeare, Marlowe, Milton."
} 
understanding of the Shakespearean text, by which, instead of analyzing different early versions of a play in order to decide which is the "true" version and which the deviations from it, we allow the various texts parallel status and analyze differences between them in terms of the distinct shape and local features of the text in which they appear. During the late Renaissance in England, the term "levelling" could refer either to an overturn of the traditional hierarchy, by which the low became high and the high low, or to an establishment of equal status among previously unequal classes of things. Although the iconoclastic thrust of textual levelling may appear to align our project with the former sense of the term, we need to imagine it rather in terms of the latter: to "level" Shakespeare is not to pull his "best" texts to the ground and to elevate the "worst" but to grant-at least provisionally and for exploratory purposes-all of the early texts equal claim to our critical attention.

Anthropologists are divided about the function of carnivalesque levelling in the early modern culture: did it reaffirm a status quo ante or did it open up a gap for new vision, new arrangements of reality? It is my hope that textual levelling will follow the latter, revisionist model-lead to a thorough rethinking of editorial practice toward all of Shakespeare's plays, not only Quarto King Lear as rehabilitated by Urkowitz, Taylor, and Warren. In some cases, particularly for single-text plays, our new "levelled" texts may look very much like the old. In other cases, however, as is already true of Lear, we may find ourselves gravitating toward a multiple editorial presentation of the plays that allows us and our students to explore deviations between texts not as symptoms of corruption but as signs of local difference.

One obvious way in which the levelling of Shakespeare texts allows us to talk about localism more easily is that some Quarto texts, unlike their Folio counterparts, announce a holiday occasion on their title page. The 1598 Quarto of Love's Labor's Lost, for example, specifies on the title page that it is being published "As it was presented before her Highnes this last Christmas" (1597 or 1598). In this case the Quarto seems to carry more specifically elitist associations than its Folio counterpart in that it advertises the play for potential readers as having been performed at court. Except for the title page, the Quarto and Folio versions of this play are quite similar: we are dealing here not so much with the devaluation of one text at the expense of another (though some editors have done that) as with a local specificity carried by one text but not by the other. The Quarto text's strong association with Christmas at court allows us to pick up a number of holiday resonances that a less specifically located text might not carry. The play's lowlifes repeatedly refer to traditional holiday pastimes- to the hobbyhorse that is "forgot," to dicing and dancing the hey, to holiday license, to "Wakes and Wassels, meetings, markets, Faires" (pp. 303, 321). These popular pastimes have their counterpart at the Court of Navarre in the gift-giving, disguisings, pageants, "Reuels, Daunces, Maskes, and merrie houres" of the aristocrats (p. 315). High and low forms of Christmas revelry forge a link

${ }^{2}$ Michael J. B. Allen and Kenneth Muir, eds., Shakespeare's Plays in Quarto (Berkeley: Univ. of California Press, 1981), p. 292. Throughout this essay Quarto references will appear in the text and refer by page number to Allen and Muir's edition. Folio references will also appear in the text and refer by through-line number to The Norton Facsimile: The First Folio of Shakespeare, ed. Charlton Hinman (New York: Norton, 1968). 
between the holiday season within the play and Elizabeth's court outside it.

Some of the pastimes in Love's Labor's Lost (wakes, the hey, and the hobbyhorse) are somewhat out of place at Yuletide, being more strongly associated with maying customs in the spring and early summer. But the play's importation of maying customs is highly functional in terms of dramatic form. At the beginning of the play, Berowne complains, "At Christmas I no more desire a Rose, / Then wish a Snow in Mayes new fangled showes; / But like of each thing that in season growes" (p. 295). To this, Dumaine's sonnet affirming that love's "Month is euer May" (p. 311) may be regarded as the appropriate lovelorn response; his attempted grafting of maying custom onto Yuletide has its folk counterpart in popular Christmas carols that borrow motifs from May Day carols. As it transpires, however, the young men's erotic courtships, like some of their pastimes, are indeed out of season. Berowne specifically links the truncated ending of Love's Labor's Lost with that of a Christmas pageant. What he has hoped for is a comedy in which Jack gets his Jill through the "courtesie" (p. 329) of the ladies; what he has instead is a play dashed "lik a Christmas Comedie" (p. 323 ), a play by country yokels that is brushed aside in medias res so that more important matters can be attended to.

Given the Christmas context of the 1598 Quarto, the four French lords' initial resolve to abjure revelry takes on a miserly and puritanical cast. When the Princess of France complains to Navarre about the baseness of her poor reception in the open fields-"I heare your grace hath sworne out Houskeeping: / Tis deadlie sinne to keepe that oath my Lord" (p . 301)—she can be seen as referring not only to his obligation as king of Navarre to entertain visiting dignitaries but more specifically to the obligation of keeping open house at Christmastide-an obligation which it is "sin" to abrogate as he and his fellows have done. In this area, too, they have acted out of season-put on Lenten abstinence at a time for banqueting and revelry. By going a-masquing to the ladies in their tents, Navarre and the others undo some of their crime of deficient hospitality, but eros in the 1598 Quarto is inextricably bound up with the liberty of the time. The movement at the end out of holiday revelry and into a harsh winter of deprivation will grant the young men a full year to disentangle sexual passion from holiday liberty and "charity."

As performed before Elizabeth, the play's mingling of caritas and eros would take on a host of additional resonances having to do with the queen's own eroticized style of rule, her tendency to bring courtiers up short, just as the French princess does in the play, if they violated the playfulness of the flirtatious games of courtiership. Performed before the queen at Christmastide, the play's depiction of the churlishness of hospitality denied could also take on a host of resonances relating to her relationships with the actual French princes after whom Navarre and his fellow hermits are named. To point to such intriguing, ephemeral parallels is, of course, to commit the high crime of "occasionalism" and to unleash a multitude of other topical interpretations that editors have much preferred to control. ${ }^{3}$ But differentiating among early texts of the play allows us to recognize that occasionalist

\footnotetext{
${ }^{3}$ Richard Levin, New Readings vs. Old Plays: Recent Trends in the Reinterpretation of English Renaissance Drama (1979; rpt., Chicago: Univ. of Chicago Press, 1982); Alfred Harbage, "Love's Labor's Lost and the Early Shakespeare," Philological Quarterly, 41 (1962), 18-36.
} 
interpretation can wax and wane according to the horizon of expectation established for a given text or performance. Later texts of Love's Labor's Lost-the 1631 Quarto and the 1623 Folio versions-are very close in action and language to the 1598 Quarto of the play but lack its specificity about occasion. A curious and under-acknowledged power is carried by such seemingly incidental localizations: the Oxford editors, for example, imply that the queen of France is more frequently given the speech prefix "Queen" in the Quarto, more frequently called "Princess" in the Folio. ${ }^{4}$ Their sense of the predominance of "Queen" in the Quarto is not borne out by a comparison of the speech prefixes in both versions of the play. It derives instead, I would suggest, from the subliminal spell exerted by the Quarto title page, with its invitation to the discovery of parallels between the royal female within the play and the one before whom it was performed.

In King Lear localization can be carried further. The Quarto text not only announces a specific holiday occasion but displays significant textual divergences from the Folio that can be correlated with that occasion. According to its 1608 title page, Quarto Lear was "played before the Kings Maiestie at Whitehall vpon S. Stephans night in Christmas Hollidayes" (p. 663). As in the case of Love's Labor's Lost, the play's several violations of laws of hospitality toward kinsmen, strangers, and the lowly would carry special resonance in such a context, for St. Stephen's was, of all the twelve nights of Christmas, the one most strongly associated with "good housekeeping" and largesse toward the poor, as is its modern counterpart, Boxing Day, in Britain and Commonwealth countries. Through the middle of the play, King Lear and his servants travel the heath from house to house very much in the manner of poor St. Stephen's Day revellers in England. To deny food and succor on St. Stephen's was, according to the unwritten laws of hospitality, unthinkable; a house denying hospitality was termed a "hard house" by suppliants and considered fair prey for breaking and entering. That language enters the play: Gloucester's house, where Lear and his servants have been shut out by Regan and the Duke of Cornwall, becomes just such a "hard house," and Kent vows to return and "force / Their scanted curtesie" (TLN 1717, $1720-21) .{ }^{5}$ Kent's speech occurs in both versions of the play, but only in the Quarto, with its evocation for readers of the feast of St. Stephen's, does the speech receive the moral validation of a holiday occasion.

If we "level" the Quarto and Folio texts instead of regarding either as intrinsically preferable to the other, we will find that in other places the St. Stephen's Day theme of social "levelling" and help for the unfortunate is more pronounced in the Quarto than in the Folio. The Quarto's mock trial scene, in which justice and folly trade places, is absent from the Folio; the Quarto refers to Lear as a "poore old fellow" (p. 682) where the Folio reads "poore old man" (TLN 1572); the Quarto, unlike the Folio, displays the faltering king actually held up by the lowly; the Quarto, through the

${ }^{4}$ Stanley Wells and Gary Taylor, eds., William Shakespeare: A Textual Companion (Oxford: Clarendon Press, 1987), p. 275 n.

${ }^{5}$ For a more extended discussion of King Lear and St. Stephen's Day, see my Puzzling Shakespeare, pp. 148-59; Margaret Hotine, "Two Plays for St. Stephen's Day," Notes and Queries, 227 (1982), 119-21; and Joseph Wittreich, "Image of that Horror": History, Prophecy, and Apocalypse in King Lear (San Marino, Calif.: Huntington Library, 1984), pp. 16-33, 57-58, and 114-22. 
comments of the two servants after the blinding of Gloucester, places more emphasis than the Folio on the justice of overturning socially sanctioned hierarchy by disobeying a corrupt master and on the particular hideousness of violence against one's host. ${ }^{6}$ If Quarto Lear has frequently looked "base" to editors by comparison with the Folio, that may be in part because of its more searching and sympathetic portrayal of baseness.

Not uncommonly, Quarto and Folio versions of a Shakespeare play can be differentiated in terms of the class identification of an implied audience, with the Folio texts generally more elevated and "discriminating" and the Quarto texts more "common." Editors have picked up this difference but tend to register any appeal to a lower level of audience as a sure sign of textual corruption. A classic case of this is their marked preference for the Folio version of The Taming of the Shrew, their unwillingness to accept any elements of the early Quarto version, The Taming of a Shrew (1594), as Shakespearean. The case of the Shrew plays is much too complex to be treated here in more than outline form. Suffice it to say that in twentiethcentury editorial practice $A$ Shrew has regularly been regarded as a "debased copy" of The Shrew, one negligently thrown together by insensitive, dunderhead actors, the likeliest candidate being the actor who played Grumio, the "lowest" character in the Shakespeare "original." And in fact the actors are portrayed as poor and lowly itinerants in the Quarto, as urbane, polished professionals - rather as editors and others have liked to imagine Shakespeare himself-in the Folio. In the Quarto the drunken Christopher Sly is central: he remains onstage almost to the end, commenting on the action; he returns after Kate's taming to remark upon his extraordinary "dream," undercutting by his reappearance the reality of the taming plot. In the Folio the character of Sly is more peripheral: he falls asleep forgotten at the end of the first act and never returns as an active presence to the play. By "levelling" even texts so intractably different as the Quarto and Folio Shrews, we will discover that the 1594 Quarto has been unacceptable to editors as "Shakespeare" at least in part because it identifies the acting company with an audience of lowlifes like Sly and hedges the play's patriarchal message with numerous qualifiers that do not exist in the Folio. ${ }^{7}$ The case of the two Shrews suggests that the differences between one text and another may sometimes register a difference in class mores and in the rituals surrounding and enforcing them.

Another kind of variable we can find in early versions of the plays is a difference in locale. One clear-cut non-Shakespearean example is Marlowe's Doctor Faustus, which is set in Wittenberg in the 1616 Quarto and in "Wertenberg" in the 1604 Quarto. If we "level" the two texts for heuristic purposes, "Wertenberg," which editors uniformly dismiss as a corruption of the "correct" location, has as much right to be an appropriate setting for the play as Wittenberg. And so, we quickly discover, it is-the first Quarto's

\footnotetext{
${ }^{6}$ See The Division of the Kingdoms; and Richard Strier, "Faithful Servants: Shakespeare's Praise of Disobedience" in The Historical Renaissance: New Essays on Tudor and Stuart Literature and Culture, Heather Dubrow and Richard Strier, eds. (Chicago: Univ. of Chicago Press, 1988), pp. 104-33.

7 I make this case at much greater length in "The Shakespearean Editor as Shrew Tamer," delivered in February 1990 as the ELR Prize Lecture at the University of Massachusetts, Amherst.
} 
"Wertenberg" is the Duchy of Württemberg, a German state carrying its own rival set of associations with the legend of Faustus. To "level" the two Quartos is to discover a consistent pattern of theological and ceremonial difference that can be correlated with the difference in locale. ${ }^{8}$

For a Shakespearean example of similar relocation, we might consider The Merry Wives of Windsor, which exists in a Quarto of 1602 with an urban setting strongly suggesting London or some provincial city, and the standard copytext, the 1623 Folio version, which sets the play in and around the town of Windsor and includes numerous topographical references to the area, its palace, park, and surrounding villages. Like several other Quartos, the 1602 Merry Wives advertises its contents on the title page as having been "diuers times Acted ... before her Maiestie, and else-where" (p. 551). In this case, unlike Love's Labor's Lost, however, it is the Folio rather than the Quarto that is thought to have had a specific royal occasion. In several places the Folio refers to the presence of the royal court at Windsor, and at the end Mistress Quickly as Fairy Queen offers a special blessing of the castle, its "Worthy" owner Elizabeth, and all its "sacred" rooms, especially the Garter Chapel and its "seuerall Chaires of Order" (TLN 2538-55). The play in its Folio form is believed to be in some way connected with the Garter ceremonies of 1597, at which Shakespeare's patron, Lord Hunsdon, was installed in the Order, the most likely date for its performance being 23 April 1597 at the Feast of the Garter before the queen at Westminster. ${ }^{9}$

I have no quarrel with this account of the Folio's occasion; what interests me particularly, however, is the way in which editors, once they have satisfied themselves as to the "correct" version of the play, dismiss the 1602 Quarto as a debased and mutilated piracy because it differs markedly from the authorized text. Instead, in accordance with our principle of levelling, I would suggest that we extend the same presumption of intentionality and integrity to the 1602 Quarto that editors have traditionally extended to the Folio. We will quickly discover that the pattern of difference is quite regular: the names of surrounding towns are similar in both versions, but in nearly every place where the Folio specifies a Windsor locale, the Quarto substitutes a more generalized location that could easily be London rather than Windsor. Falstaff's great "buck-basket" is carried "among the Whitsters in Dotchet Mead" in the Folio (TLN 1363-64), merely "to the Launderers" in the Quarto (p. 565). (The fat knight ends up in the same river in either case, since both London and Windsor are on the Thames.) In the Folio one set of characters runs madly "through the Towne [of Windsor] to Frogmore" while others run "about the fields with mee through Frogmore" (TLN 1134-35, 1144-45). In the Quarto they go "through the fields to Frogmore" (p. 563)-a slight change, but one that makes the line more parallel to the London experience of going "through the fields" to reach the open countryside. Characters in the Folio text habitually offer exclamations and comparisons anchored in their locale: "as any is in Windsor" (TLN 866), "neuer a woman in Windsor" (TLN 514-15), "for ye welth of Windsor castle" (TLN 1543). This trick of language does not exist in the Quarto text.

\footnotetext{
${ }^{8}$ Leah S. Marcus, "Textual Indeterminacy and Ideological Difference: The Case of Doctor Faustus," RenD, 20 (1989), 1-29.

${ }^{9}$ Leslie Hotson, Shakespeare versus Shallow (Boston: Little, Brown and Co., 1931), pp. 111-22.
} 
In nearly every case where the Folio refers to some feature of rural life in Windsor, enlivened by the presence of the court, the Quarto creates a more identifiably urban equivalent, but without any mention of the court. The Folio has Simple hiding in a "Closett" and Doctor Caius on his way to court (TLN 438-65); the Quarto has Simple hiding in a "Counting-house" and does not specify the Doctor's destination (p. 557). Mistress Quickly's long description of the court's visit to Windsor in 2.2 of the Folio (TLN $829-46)$ does not exist in the Quarto. The Folio's 2.2 has Ford praising Falstaff's "war-like, court-like" preparations; in the Quarto, Falstaff is simply "A man of such parts that might win 20. such as she" (p. 561); and in several other places, similarly, references to court exist in the Folio that do not in the Quarto. ${ }^{10}$ Instead of the Folio's fairy visits to "Windsor-chimnies" and the castle, which must be kept clean since "Our radiant Queene, hates Sluts, and Sluttery" (TLN 2525-28), the Quarto has Puck sending Peane to the "countrie houses" and Pead dispatched to a more recognizably urban setting:

go you \& see where Brokers sleep,

And Foxe-eyed Seriants with their mase,

Goe laie the Proctors in the street,

And pinch the lowsie Seriants face. ...

And of course, the Folio's long, elaborate blessing of the castle itself and St. George's Chapel does not exist in the Quarto:

Search Windsor Castle (Elues) within, and out.

Strew good lucke (Ouphes) on euery sacred roome,

That it may stand till the perpetuall doome,

In state as wholsome, as in state 'tis fit,

Worthy the Owner, and the Owner it.

The seuerall Chaires of Order, looke you scowre

With iuyce of Balme; and euery precious flowre,

Each faire Instalment, Coate, and seu'rall Crest,

With loyall Blazon, euermore be blest. ...

(TLN 2538-46)

Even Falstaff's language is sometimes more rural in the Folio than in the Quarto. In the Folio he says, "I will vse her [Mistress Ford] as the key of the Cuckoldy-rogues Coffer, \& ther's my haruest-home" (TLN 1026-28). For "haruest-home" the Quarto has "randeuowes [rendezvous]" (p. 562). And finally, his punishment as "Herne the Hunter" in the Folio is imagined as part of an elaborate myth surrounding a long-dead keeper of Windsor Forest who haunts a giant oak known by all as "Hernes Oake"-a mysterious and "ancient" rural "tale" that is apparently Shakespeare's invention (TLN 2150-60). In the Quarto, "Horne the Hunter" is the subject of superstition but is not associated with an ancient keeper of Windsor Forest, a giant oak,

${ }^{10}$ See Hinman, TLN 445, 510, 1276, 1332-33, 1397 (the court of France), 1502 (the fashion of France), 2110, and 2304. The equivalent references in the parallel-text edition of The Bankside Shakespeare I, ed. Appleton Morgan (New York: Shakespeare Society, 1888), are on pages $75,79,125,129,133,179$, and 193. I have found only one reference to court in the Quarto that does not exist in the Folio; it is by Falstaff himself and does not imply the court's close proximity (Allen and Muir, p. 577). 
or any topographical fable. He haunts "field" and "woods" more generally, and is, through his name and lack of other associations, more directly a figure of cuckoldry than the mighty Herne of the Folio. As Horne, Falstaff still calls himself the fattest stag "In all Windsor forrest" (p. 575), but that is almost the Quarto text's only reference to Windsor aside from the title itself. ${ }^{11}$ The Folio version of Merry Wives is a comedy of small town and rural life, steeped in rustic customs and topography but also imbued with the "high" presence of the royal court; the Quarto version is "lower," more urban, closer to the pattern of city or "citizen" comedy.

Both versions of Merry Wives are teeming with folk rituals, but the way we interpret them will depend on which version we choose. Northrop Frye, Jeanne Roberts, and others have called attention to the scapegoating pattern in The Merry Wives of Windsor: in keeping with ancient seasonal folk ritual, Falstaff is symbolically slain and cast out to restore the community to health. After his punishment in the guise of Herne, he calls himself "Iacke-a-Lent" in the Folio (TLN 2611), which suggests a Shrovetide context like that which C. L. Barber has offered for Falstaff as scapegoat in the Henry IV plays; Jeanne Roberts prefers to associate the play with Halloween and All Saints' Day, and in fact Merry Wives was performed at the court of James I on 4 November $1604 .{ }^{12}$ Even more suggestive is the fact that Falstaff's various trials, particularly the last, echo the pattern of the village "rough music," charivari, or skimmington, which was not a seasonal observance but a rather free-form ritual shaming performed as need arose. Charivari often culminated in the ducking of an adulterer in the local pond or stream, a punishment that resembles Falstaff's first trial in the buckbasket. Often, men in the charivari appeared in drag, and quite regularly the person representing its male target was carted about dressed as a woman, just as Falstaff is in his second trial, when he is beaten as the Witch of Brainford. But horns for an adulterer were an even more common feature of the charivari. In some versions townspeople dressed a symbolic victim in horns (like Horne or Herne the hunter) and punished him as a way of shaming sexually deviant neighbors into conformity with or departure from the community. Falstaff is both symbolic victim of the ritual and its real target since he is the one who has assailed the virtue of the wives. ${ }^{13}$

\footnotetext{
${ }^{11}$ I have noticed two others: "halfe Windsor" (p. 566), and "all Windsor" (p. 576). The presence of these few Windsor references in a text otherwise empty of them could be taken as evidence that the Quarto is a revised version of the Folio text; on the other hand, as will be shown below, there are ways in which the Folio seems revised from the Quarto-strong evidence that neither text is the "original."

${ }^{12}$ See Northrop Frye, Anatomy of Criticism: Four Essays (Princeton, N.J.: Princeton Univ. Press, 1957), p. 183; Jan Lawson Hinely, "Comic Scapegoats and the Falstaff of The Merry Wives of Windsor," Shakespeare Studies, 15 (1982), 37-54; C. L. Barber, Shakespeare's Festive Comedy: A Study of Dramatic Form and its Relation to Social Custom (1959; rpt., New York: Meridian Books, 1963), pp. 205-21; François Laroque, Shakespeare et la fête: Essai d'archéologie du spectacle dans l'Angleterre élisabéthaine (Paris: Presses Universitaires de France, 1988), pp. 283-85; and Jeanne Addison Roberts, Shakespeare's English Comedy: The Merry Wives of Windsor in Context (Lincoln: Univ. of Nebraska Press, 1979), pp. 78-83.

${ }^{13}$ David Underdown, "The Taming of the Scold: the Enforcement of Patriarchal Authority in Early Modern England" in Order and Disorder in Early Modern England, Anthony Fletcher and John Stevenson, eds. (Cambridge: Cambridge Univ. Press, 1985), pp.116-36. See also Underdown, Revel, Riot, and Rebellion: Popular Politics and Culture in England 1603-1660 (Oxford: Clarendon Press, 1985), pp. 102-11; and Buchanan Sharp, In Contempt of All Authority: Rural Artisans and Riot in the West of England 1586-1660 (Berkeley: Univ. of California Press, 1980).
} 
In terms of our inquiry here, however, the most interesting aspect of the play's various echoes of folk customs is how differently we are likely to analyze their function in the play, depending on whether we are considering the Quarto or the Folio. In the Quarto version Falstaff is almost the only character with courtly associations: his punishment has very much the quality of middle-class townspeople's ritualized expulsion of the corrupting intrusiveness of the court, its attempted seductions and financial exploitation. In the Quarto version and that version only, courtiers and would-be courtiers are mocked by name. Brooke (Broome in the Folio) has been taken by editors as a thrust against one of the Lords Cobham, whose surname was Brooke; the thieving "cosen garmombles" of the Quarto (changed to "Cozen-Iermans" in the Folio) almost certainly glances at the German Count Mompelgard (later duke of Württemberg), who had toured England in the early 1590s and made himself a laughingstock at court through his eagerness to be installed as a Knight of the Garter. He was expected to be installed in the 1597 Garter ceremonies, with which the Folio Merry Wives is associated, but did not attend; and indeed in the Folio version an unnamed German duke connected with the cousin-Germans is expected at court but has not arrived (TLN 2109-19).

The Folio is much kinder than the Quarto to figures associated with the court. Not only are the references to actual personages disguised, but the population of Windsor within the play is, for the most part, deferential. The Fairy Queen and her minions actively bless Windsor Castle, its special knights, and its queen. Falstaff cannot personify an innate courtly corruption since the court is imagined as worthy. He is rather the debased imitator of courtly ideals articulated within the play itself. While the Quarto version can be seen as the citizenry's expulsion of a debauchery associated with courtliness in the form of corpulent Falstaff, in the Folio the image of the court and the Windsorites work together against Falstaff. The ritual function of the charivari is more strongly emphasized in the Folio: in that version, as they devise their trap for Herne the Hunter, the wives repeatedly aver that Falstaff must be "publiquely sham'd" (TLN 2101-03). But in the Folio the charivari, which was historically a ritual under village or town control, has been colonized by the court. Given the Garter context of the Folio version, Falstaff's punishment there, which follows directly upon the blessing of Windsor Castle and the Garter Knights, takes on the quality of a ritual expulsion of an unworthy desecrator of the rite as a way of cleansing the Order itself. He is a "corrupted hart" deserving the shame of "Hony Soit Qui Mal-y-Pence" (TLN 2551). ${ }^{14}$ Moreover, in the Folio, Anne Page's successful wooer, Fenton, is also of the court. Master Page distrusts him because "hee kept companie with the wilde Prince, and Pointz: he is of too high a Region, he knows too much" (TLN 1332-34); Page finally learns by the end that things "high" and courtly do not necessarily merit distrust. In the denouement of this text, at least by comparison with the Quarto, the

\footnotetext{
${ }^{14}$ For Garter interpretations of Falstaff's punishment, see Hinely (cited in n. 12, above) and Peter Erickson's analysis in "The Order of the Garter, the cult of Elizabeth, and class-gender tension in The Merry Wives of Windsor," Jean E. Howard and Marion F. O'Connor, eds., Shakespeare Reproduced: The text in history and ideology (New York and London: Methuen, 1987), pp. 116-42. Although both are valuable, neither of these studies distinguishes between the Quarto and Folio versions.
} 
court and Windsor citizenry are brought into closer proximity through the marriage.

It is tempting to account for the differences between Quarto and Folio Merry Wives in terms of a difference in audience: the Quarto version, even though it may, as its title page asserts, have been performed before the queen, seems more oriented toward a middle-class urban public; the Folio, toward the court itself. Such speculation is, of course, hazardous but is nonetheless supported by other elements of the play. In the Quarto the relationship between Anne and Fenton is presented in a sentimental and romantic vein; theirs is a love match predating the play. We never find out how much Anne is "worth" in money, and it is clear that Fenton, although initially attracted to her, as he admits, for her wealth, remains attached to her out of love. In the Folio the match is only being negotiated as the play itself unfolds. Anne is explicitly worth $£ 700$ plus the inheritance expected from her father. Fenton is distinctly more mercenary throughout, less convincingly in love with Anne than with her money. The Quarto's sentimental benevolence extends to other characters like Ford and even to Falstaff himself: in that text, once properly reformed, he is forgiven his debt of $£ 20$ to Ford; in the Folio he is expected to pay up. ${ }^{15}$ We would expect the more romanticized version of Anne and Fenton's relationship to appeal more strongly to a middle-class urban audience, and the Folio's more skeptical and mercenary portrayal of middle-class mores to appeal more strongly to a "higher" audience more closely identified with the court. Given that the valorization of wedded love was more prominently associated during the period with the middle orders than with the aristocracy, to which it was only gradually beginning to spread, the Quarto version of the play can be seen as articulating a "lower" pattern of class expectations about family life than does the Folio. The sexual politics of the two versions are also subtly different: in the Quarto the wives and Mistress Quickly win an unequivocal victory against the court and jealous husbands; in the Folio they defeat Falstaff, but to the extent that their actions further Fenton's match, they are cementing an alliance with the court or, in a less charitable interpretation, helping a young courtier cash in on the market for middleclass wives even as they thwart the old courtier's rather similar ambitions. In the case of Merry Wives, as for some of the other plays we have discussed, use of a conflated text, in which Folio readings are combined with occasional borrowings from the Quarto, is likely to blur analysis of such social transactions because it intermingles patterns that are relatively distinct in either version when considered separately. In order to read Shakespeare in terms of the plays' engagement of local matters, of early modern patterns of ritual observance and interaction, we need to read "levelled" texts.

This swift and speculative essay is designed more to pique interest in the

${ }^{15}$ For Falstaff's payment compare the Quarto, page 577, and the Folio, TLN 2650-54. For Mistress Ford's greater sympathy for her husband in the Quarto, see the conversation between Mistresses Ford and Page at page 567 and its equivalent at TLN 1505-17. On Anne's inheritance and Fenton's tendencies to think in terms of money, see TLN 50-60, Anne and Fenton's wooing scenes in both versions, and page 575 versus TLN 2398-99. In the final scene of the Folio, Fenton asserts that he and Anne have been "long since contracted" (TLN 2705) but apparently not from before the beginning of the play. In the Bankside parallel-text version, the cited passages are on pages 212-13, 138-39, 51, 196-97, and 217. 
project of levelling Shakespeare than to constitute a definitive statement on the relationship of any one text to another. In the case of The Merry Wives of Windsor, as for the other plays I have surveyed briefly here, we are at the beginning of a new scholarly venture that can be described (somewhat bombastically) as the mobilization of a holistic, New-Critical interpretive method (somewhat leavened with historicism) in order to combat traditional editorial practice for the purpose of advancing a poststructuralist sense of the multiplicity of the Shakespearean text and the undecideability of that bundle of conflicting energies that we like to call Shakespeare himself. I have tried for sharpness of definition in my differentiation between variant Quarto and Folio texts because I hope to demonstrate that, even in terms of the editors' own preferred interpretive strategies, "bad" texts can readily be shown to be "good" if we suspend our need to rank them hierarchically. The impact of textual levelling upon our analysis of Shakespearean folk customs and topography should be clear, since it is a corollary of the method itself: we will be less able, at least for a time, to talk in terms of archetypes and large ritual patterns, more able to talk about historical particularity and local difference. 